\title{
Combined effects of water status and iron deficiency chlorosis on grape composition in
}

\section{non-irrigated vineyards}

\author{
María-Rosa González $^{1}{ }^{(0)}$, Girma Hailemichael ${ }^{2}$, Álvaro Catalina ${ }^{1(0)}$, Pedro Martín ${ }^{1 *(1)}$
}

1Universidad de Valladolid/Escuela Técnica Superior de Ingenierías Agrarías - Depto. de Producción Vegetal y Recursos Forestales, Av. de Madrid, 57 - 34004 - Palencia - Spain.

${ }^{2}$ Jimma Agricultural Research Center, PO Box 192 - Jimma Oromia - Ethiopia

*Corresponding author <pmartinp@pvs.uva.es>

Edited by: Axel García y García

Received March 21, 2018

Accepted June 05, 2018

\begin{abstract}
Although water deficit and iron deficiency chlorosis are common environmental stresses in the Mediterranean area, few data are reported in the literature on their effects on vineyards, when acting simultaneously. The main objective of this research was to study the combined effects of iron deficiency and water status on vigor, yield and fruit composition in rainfed vineyards. Moreover, the investigation aimed to evaluate the feasibility of using foliar chlorophyll content (Chl) and predawn leaf water potential (LWP), measured at veraison, to assess potential quality of grapes in the framework of precision viticulture. For this, 24 non-irrigated 'Tempranillo' vineyard subzones were monitored in Ribera del Duero (North-Central Spain) during three consecutive seasons (2011-2013). The analysis of variance and principal component analysis showed that malic acid concentrations of the must were impacted only by $\mathrm{Chl}$, whereas total soluble solids and total acidity were mainly modified by LWP. Both water and iron status reduced yield and berry weight and had additive effects on extractable anthocyanin content in grapes, total polyphenol index and color density of the must. In all seasons, the ratio Chl/LWP had a better predicting value for quality parameters of these grapes than leaf area index, $\mathrm{Chl}$ or LWP individually. The present work demonstrates the potential interest of physiological indexes combining water status and foliar chlorosis as indicators of grape phenolic potential in rainfed vineyards affected by iron deficiency.

Keywords: Vitis vinifera L., chlorophyll, drought, leaf area index, stress
\end{abstract}

\section{Introduction}

Water deficit and iron nutritional deficiency (iron chlorosis) are two frequent types of environmental stresses that cause serious economic losses in grapevine production in the Mediterranean area. In non-irrigated vineyards, local variation in soil conditions, such as texture, useful depth, drainage, $\mathrm{pH}$ or active limestone content, can generate a wide variability in vine-to-vine water and/or iron status, affecting yield and grape composition (Cortell et al., 2005; Li et al., 2017; Meggio et al., 2010).

In different ways, water and iron stress decline the photosynthetic activity in plants. While iron deficiency leads to a decrease in the synthesis of photosynthetic pigments (Val et al., 1987) and a lower efficiency of photosystem II (Bavaresco et al., 2006; Hailemichael et al., 2016), water deficit causes marked stomatal closure, reducing availability of $\mathrm{CO}_{2}$ in leaf mesophyll (Flexas et al., 2002). The loss of photosynthetic capacity depresses yield and vigor both in iron (Echeverría et al., 2017; Tagliavini and Rombolà, 2001; Martín et al., 2007) and water (Balint and Reynods, 2014; Van Leeuwen et al., 2009) affected grapevines, and reduces synthesis and accumulation of substances in the fruit during ripening (Pirie and Mullins, 1980; Ojeda et al., 2002). Nevertheless, moderate stress levels can have positive effects on grape quality, as the plants restrict vegetative growth, they have less yield and smaller berries (Roby and Matthews, 2004; Balint and Reynolds, 2017), and concentrate constituents, such as phenolic compounds, which are responsible for color, astringency and bitterness of red wines (Zoecklein et al., 1990).

A number of studies have been conducted to evaluate impacts of water or iron stress on grapevines, individually, under controlled conditions (i.e. irrigation experiments). However, very few data are available in the literature on their effects on the field, when acting simultaneously. The investigation in this line is an essential previous step in precision viticulture to develop combined physiological indexes, able to delimit quality zones better than traditional vegetation indexes, based on foliage density or vigor (Arnó et al., 2009).

This work aimed to (i) study the additive and interactive effects of foliar chlorophyll content and predawn leaf water potential, measured at veraison, on vine vigor, yield and fruit composition, and (ii) evaluate feasibility of foliar chlorosis and water status measurements, alternatively to vegetation indexes, to assess potential quality of grapes in rainfed vineyards affected by iron chlorosis.

\section{Materials and Methods}

\section{Study site description}

The study was conducted in the 2011, 2012 and 2013 seasons, on 24 non-irrigated vineyard subzones located in Pesquera de Duero (latitude $41^{\circ} 38^{\prime} 34^{\prime \prime} \mathrm{N}$, longitude $4^{\circ} 09^{\prime} 27^{\prime \prime} \mathrm{W}$, Ribera del Duero Appellation of Origin area, center-northern Spain), at $800 \mathrm{~m}$ above sea level. The subzones $(10 \mathrm{~m} \times 10 \mathrm{~m}$ each) were selected with different soil depths, soil textures and topography, to ensure maximum variability in water availability 
across the sites, according to the study purposes (Martín et al., 2008; Hailemichael et al., 2016). The vineyards corresponded to 'Tempranillo' cultivar, 10 to 14 years old, grafted onto 110-Richter rootstock. Vines were spaced $3 \mathrm{~m} \times 1.5 \mathrm{~m}\left(2222\right.$ plants $\left.\mathrm{ha}^{-1}\right)$ and trained in a vertical shoot positioning system. Eight spurs per vine, with two buds per spur, were retained during winter pruning.

The soils in the study area are calcareous, very basic and poor in organic matter, with high variability in extractable potassium, phosphorus and magnesium contents (Martín et al., 2008; Zarco-Tejada et al., 2013). Texture ranged from medium to medium-weight. Concentrations of active carbonate $(3-16 \%)$ and diethylenetriaminepentaacetic acid (DPTA) extractable iron (2.3-6.4 $\left.\mathrm{mg} \mathrm{kg}^{-1}\right)$ were highly heterogeneous in the area. These soil properties, along with rootstock sensitive to lime (110-Richter), led to different levels of iron deficiency chlorosis in the vineyards, from unaffected to moderately-affected.

The study site has Mediterranean climate, with low temperatures in winter and hot and dry summers. The monthly values of temperature and precipitation registered in 2011, 2012 and 2013 are shown in Table 1. Rainfall ranged from $137 \mathrm{~mm}$ to $173 \mathrm{~mm}$ from Apr 1 to Sept 30 in the three seasons. Without irrigation, these insufficient water supplies in soils, varying in texture and root explorable depth, ensured a broad variability of grapevine water status in the study site.

\section{Field data collection}

In 2011, leaf samples for mineral analysis were collected at veraison stage. Sixty fully expanded leaves were collected from each subzone following the recommendations of the International Organisation of Vine and Wine (1996). Nitrogen concentration was determined directly on the dried plant material by the Kjeldahl method. To determine the rest of nutrients, the samples were oven dried at $450{ }^{\circ} \mathrm{C}$, extracting the minerals with $2 \mathrm{~N} \mathrm{HCl}$. In the extracts, $\mathrm{P}$ and $\mathrm{B}$ were analyzed spectrophotometrically, $\mathrm{Ca}, \mathrm{Mg}, \mathrm{Fe}, \mathrm{Mn}, \mathrm{Cu}$ and $\mathrm{Zn}$ by atomic absorption spectroscopy, and $\mathrm{K}$ by atomic emission spectroscopy. All results were expressed in percentage on dry matter basis.

Each season, data on leaf area index (LAI), foliar chlorophyll content (Chl) and predawn leaf water potential (LWP) were recorded at veraison, when there was an average of $75 \%$ of colored berries in all study subzones. LAI was measured according to Sánchez-de-Miguel et al. (2010) from 20 representative shoots in each subzone, using a portable laser leaf area meter. Chlorophyll content data were recorded by a portable colorimeter in 30 leaves in each subzone, always choosing the fourth or fifth leaf counting from the first lead of the apex. The chlorophyll content per leaf area unit $\left(\mu \mathrm{g} \mathrm{cm}^{-2}\right)$ was calculated from the colorimeter readings $(\mathrm{CR})$ by a regression line obtained previously for cv. Tempranillo $\left(\mathrm{R}^{2}=\right.$ $0.91 ; p<0.0001)$ :

$\mathrm{Chl}=6.0817 \cdot \mathrm{CR}+7.6084$

Leaf water potential was measured during two hours before dawn. In each subzone, values were taken with a Scholander pressure chamber from six fully expanded leaves located at the fourth or fifth node from the apex.

Yield, yield components (number of clusters per shoot, mean weight of clusters and 100 berry weight) and winter pruning weight (PW) were determined in subzones for each season.

\section{Grape composition analysis}

Harvesting was performed after the mean value of total soluble solid content of the must (TSS) in all study subzones reached $22^{\circ}$ Brix. At that moment, two samples of 100 berries from each subzone were collected. The must obtained from the first sample was used to determine TSS, total acidity (TA), tartaric and malic acid concentration, total polyphenols index (TPI), $\mathrm{pH}$ and potassium content, according to the European official methods of analysis (European Commission, 1990). The berries from the second sample were used to analyze

Table 1 - Monthly mean values of maximum $\left(T_{\max }\right)$, minimum $\left(T_{\min }\right)$, average $\left(T_{\text {ave }}\right)$ temperature $\left({ }^{\circ} \mathrm{C}\right)$, and total precipitation $(P$, in mm) collected during the years studied from station VA07 - Valbuena de Duero (Valladolid, Spain).

\begin{tabular}{|c|c|c|c|c|c|c|c|c|c|c|c|c|c|}
\hline Year & Variables & Jan & Feb & Mar & Apr & May & June & July & Aug & Sept & Oct & Nov & Dec \\
\hline \multirow{4}{*}{2011} & $\mathrm{~T}_{\max }$ & 7.6 & 11.9 & 13.4 & 20.6 & 24.0 & 26.8 & 28.3 & 30.0 & 28.1 & 22.2 & 12.9 & 9.0 \\
\hline & $\mathrm{T}_{\min }$ & 1.0 & -1.1 & 2.3 & 6.2 & 7.3 & 9.4 & 9.9 & 12.4 & 9.0 & 3.5 & 9.0 & -0.8 \\
\hline & $\mathrm{T}_{\mathrm{ave}}$ & 4.1 & 4.6 & 7.4 & 13.1 & 15.7 & 18.2 & 19.6 & 21.2 & 18.4 & 12.6 & 8.1 & 3.5 \\
\hline & $\mathrm{P}$ & 39 & 19 & 35 & 32 & 18 & 7 & 3 & 57 & 20 & 19 & 42 & 15 \\
\hline \multirow{3}{*}{2012} & $\mathrm{~T}_{\max }$ & 7.8 & 9.2 & 16.6 & 13.0 & 23.1 & 28.1 & 29.8 & 30.8 & 25.2 & 18.5 & 12.2 & 9.1 \\
\hline & $\mathrm{T}_{\min }$ & -2.1 & -4.3 & -0.3 & 2.5 & 6.4 & 9.9 & 10.2 & 11.4 & 9.6 & 4.7 & 2.1 & 0.7 \\
\hline & $\mathrm{P}$ & 2 & 0 & 21 & 95 & 41 & 18 & 6 & 1 & 23 & 24 & 48 & 33 \\
\hline \multirow{4}{*}{2013} & $\mathrm{~T}_{\max }$ & 8.7 & 9.2 & 11.8 & 15.1 & 17.3 & 24.5 & 32.3 & 30.2 & 26.1 & 19.1 & 11.3 & 8.9 \\
\hline & $\mathrm{T}_{\min }$ & 0.1 & -1.4 & 2.2 & 2.6 & 3.7 & 8.2 & 13.1 & 11.6 & 9.6 & 7.4 & 1.9 & -2.4 \\
\hline & $\mathrm{T}_{\mathrm{ave}}$ & 4.1 & 3.4 & 6.6 & 8.9 & 10.4 & 16.2 & 22.7 & 20.9 & 17.6 & 12.8 & 6.5 & 2.4 \\
\hline & $\mathrm{P}$ & 51 & 37 & 137 & 48 & 37 & 22 & 8 & 5 & 53 & 70 & 10 & 55 \\
\hline
\end{tabular}


total anthocyanin (TAN) and easily extractable anthocyanin (EA) contents, following the methodology described by Saint-Cricq de Gaulejac et al. (1998). TAN and EA were expressed based on berry fresh weight. The CIELab color space coordinates of musts were obtained with a UV/VIS spectrophotometer.

\section{Statistical analysis}

To separate the effects of season, water status and iron chlorosis incidence on vigor, yield and grape composition parameters, factorial analysis of variance (ANOVA) and the Tukey test were performed. For this, the subzones were previously classified into groups with high and low LWP, and with high and low Chl. The limit values for segmentation were the means of both explanatory variables in the subzones throughout the three years of study: $-0.837 \mathrm{MPa}$ and $99.9 \mu \mathrm{g} \mathrm{cm}^{-2}$, respectively.

The feasibility to predict yield and grape composition parameters by LWP and Chl was tested with linear regressions. On the other hand, the principal component analysis (PCA) was conducted on the correlation matrix, taking into account the main variables studied. All data analyses were performed with version 9.2 of SAS statistical software (Statistical Analysis System, version 9.2).

\section{Results and Discussion}

The records of LWP (Table 2) indicated moderate to severe water deficit in the studied subzones, according to ranges from Van Leeuwen et al. (2009). A rainfall of $22 \mathrm{~mm}$ was recorded 15 days before veraison in 2011 while, in 2012 and 2013, there were no rain events greater than $5 \mathrm{~mm}$ in the two months previous to the LWP data collection. Thus, the plants registered in 2011 a more favorable water status at veraison than in 2012 and 2013, showing wider variability between subzones (Table 2).

The mean values of $\mathrm{Chl}$, measured at veraison in the upper part of the canopy, increased from 2011 to 2013, keeping coefficients of variation above $21 \%$ in the three seasons (Table 2). Chl is strongly influenced by nutrient status in the study site, including the inci-

Table 2 - Mean values and standard deviation (SD) of foliar chlorophyll content (Chl) and predawn leaf water potential (LWP), registered at veraison in the subzones studied.

\begin{tabular}{lccc}
\hline Year & Value & Chl & LWP \\
\hline \multirow{2}{*}{2011} & & $\mu g \mathrm{~cm}^{-2}$ & $\mathrm{MPa}$ \\
& Mean & $87.50 \mathrm{~b}$ & $-0.60 \mathrm{a}$ \\
2012 & $\mathrm{SD}$ & 21.12 & 0.17 \\
\hline \multirow{2}{*}{2013} & Mean & $95.80 \mathrm{ab}$ & $-0.89 \mathrm{~b}$ \\
& $\mathrm{SD}$ & 24.66 & 0.12 \\
\hline In each column, mean values followed by the same letter are not significantly
\end{tabular}
different $(p>0.05)$ in the Tukey test. dence of iron deficiency chlorosis (Martín et al., 2008). In previous studies, Hailemichael et al. (2016) obtained no consistent correlations between LWP and Chl of subzones therefore both variables could be considered independent.

The Pearson coefficient (Table 3) (data available only from 2011) showed that Chl was not correlated with petiolar Fe content. This agrees to Bavaresco et al. (1999), who demonstrated that foliar total Fe level is not a valid parameter to detect iron deficiency in grapevines. The Mn content in the petiole was negatively correlated with Chl (Table 3) and positively correlated with total soil carbonates $(\mathrm{r}=0.69 ; p<0.01)$. Mn is antagonistic to $\mathrm{Fe}$ and might accumulate in leaves from plants affected by iron chlorosis (Millaleo et al., 2010). The negative correlation between $\mathrm{Chl}$ and $\mathrm{Mg}$ in the petiole content might also be due to antagonism between both nutrients, as proven in other species (Agarwala and Mehrotra, 1984).

The results of factorial ANOVA (Table 4) show that the effects of season on vigor, yield components and grape composition parameters were almost always highly significant, evidencing the existence of great variability of meteorological conditions in the years of study. There were no interaction effects between LWP and Chl at $p<0.05$ significance level.

Vine vigor, measured as PW or LAI, was not related to water status at veraison (Table 4). Many studies indicate that restriction in vine water uptake limits shoot growth and reduces vigor (Koundouras et al., 2006; Van Leeuwen et al., 2009); however, in the present investigation, LWP was measured out of the vegetative growth period and would not be a good indicator of vine vigor.

Pruning weight tended to decrease in chlorotic subzones versus non-chlorotic, with significant differences in 2012 (0.72 kg per vine versus $1.05 \mathrm{~kg}$ per vine). As a consequence of the decrease in photosynthetic capacity, iron deficiency reduces annual vegetative growth in grapevines (Gruber and Kosegarten, 2002; Tagliavini and Rombolà, 2001). Moreover, iron deficiency has a cu-

Table 3 - Pearson correlation ( $r$ ) between foliar chlorophyll content and petiole nutrient content, on dry matter, in the subzones studied (data obtained at veraison in 2011).

\begin{tabular}{ll}
\hline Nutrient & $r$ \\
\hline $\mathrm{N}$ & 0.20 \\
$\mathrm{P}$ & 0.37 \\
$\mathrm{~K}$ & 0.24 \\
$\mathrm{Ca}$ & 0.35 \\
$\mathrm{Mg}$ & $-0.51^{* *}$ \\
$\mathrm{Fe}$ & 0.37 \\
$\mathrm{Cu}$ & $0.42^{*}$ \\
$\mathrm{Zn}$ & 0.10 \\
$\mathrm{Mn}$ & $-0.41^{*}$ \\
$\mathrm{~B}$ & 0.32 \\
\hline
\end{tabular}

${ }^{*}$ Significant $p<0.05 ;{ }^{* *}$ Significant $p<0.01$. 
Table 4 - F-values of the factorial analysis of variance of vigor, yield and grape quality data obtained in vineyard subzones with high and low predawn leaf water potential (LWP) and high and low foliar chlorophyll content at veraison (Chl), in 2011, 2012 and 2013.

\begin{tabular}{|c|c|c|c|c|c|}
\hline \multirow{2}{*}{ Parameters } & \multicolumn{5}{|c|}{ Source of variation } \\
\hline & Model & Year & LWP & $\mathrm{Chl}$ & LWP* $\mathrm{Chl}$ \\
\hline \multicolumn{6}{|l|}{ Vigor and yield } \\
\hline Pruning weight & $19.47^{* *}$ & $31.43^{* *}$ & 1.16 & $5.12^{*}$ & 0.62 \\
\hline Leaf area index & $8.78^{*}$ & $16.67^{\text {* * }}$ & 1.85 & $4.51^{*}$ & 0.01 \\
\hline Yield & $5.79^{* *}$ & 2.50 & $3.41^{* *}$ & $6.40^{*}$ & 1.97 \\
\hline Clusters/shoot & 1.17 & 1.39 & 0.80 & 1.32 & 0.38 \\
\hline Cluster weight & $9.92^{* *}$ & $4.69^{*}$ & $9.22^{* *}$ & $5.54^{*}$ & 0.71 \\
\hline 100 berry weight & $24.94^{* *}$ & $29.16^{* *}$ & $2.62^{* *}$ & $11.44^{* *}$ & 0.17 \\
\hline \multicolumn{6}{|l|}{ Grape composition } \\
\hline Total soluble solids (Brix) & $11.23^{* *}$ & $23.91^{\text {* * }}$ & $4.00^{*}$ & 0.43 & 1.33 \\
\hline Titratable acidity & $28.56^{* *}$ & 58.28 ** & $5.13^{*}$ & 2.35 & 1.00 \\
\hline $\mathrm{pH}$ & $53.67^{* *}$ & $113.40^{* *}$ & $6.55^{*}$ & $5.88^{*}$ & 0.16 \\
\hline Malic acid & $178.06^{* *}$ & $410.39^{* *}$ & 0.91 & $4.64^{*}$ & 0.28 \\
\hline Tartaric acid & $345.09 * *$ & 593.30 * * & 0.21 & 2.80 & 1.37 \\
\hline Potassium & $56.95^{\text {* * }}$ & $104.80^{* *}$ & $0.04^{*}$ & $0.01^{*}$ & 0.61 \\
\hline Total polyphenol index & $42.10^{* *}$ & 91.00 ** & $5.18^{*}$ & $12.46^{\star *}$ & 1.22 \\
\hline Total anthocyanins & $21.80^{* *}$ & $47.80^{* *}$ & $12.18^{*}$ & 3.21 & 1.14 \\
\hline Extractable anthocyanins & $56.16^{* *}$ & $123.41^{\text {* * }}$ & $4.54^{*}$ & 4.24 * & 0.07 \\
\hline \multicolumn{6}{|l|}{ Must color } \\
\hline$C^{*}$ & $43.07^{* *}$ & $70.97^{* *}$ & 0.33 & $5.99^{*}$ & 3.35 \\
\hline $\mathrm{h}$ & $29.21^{* *}$ & $44.19^{* *}$ & 0.05 & $10.74^{* *}$ & 1.40 \\
\hline $\mathrm{L}$ & $15.80^{* *}$ & $25.04^{* *}$ & $4.34^{*}$ & $9.93^{* *}$ & 1.21 \\
\hline$a^{*}$ & $45.84^{* *}$ & $70.75^{* *}$ & 0.79 & $15.36^{* *}$ & 0.36 \\
\hline$b^{*}$ & $22.49^{* *}$ & $32.77^{\text {* * }}$ & 1.63 & 0.86 & 0.56 \\
\hline
\end{tabular}

mulative effect on plants year after year, which would increase differences in vigor between affected and nonaffected subzones in the vineyard.

Water status and Chl had an additive effect on yield, increasing both mean cluster weight and berry size (Table 4). It is well known that a limitation in vine water uptake reduces yield components (Koundouras et al., 2006; Van Leeuwen et al., 2009) in a similarly to low iron availability (Bavaresco et al., 2005; Balint and Reynolds, 2014; Martín et al., 2007). Subzones combining both iron and water stress conditions registered the lowest values of these variables in all years of study. Total yield losses in these subzones, compared to the not-stressed ones, accounted for $40 \%$ in 2013 and $51 \%$ in 2012. Berry weight decreased between $19 \%$ in 2013 and $23 \%$ in 2011. At least in water stressed plants, the loss of berry size might be mostly due to a smaller pulp, since the weight of skin and seeds seems to be less affected by water deficit (Roby and Matthews, 2004).

Water and iron status at veraison affected differently grape composition parameters, without interactions between them (Table 4). Technological maturity (TSS and TA) was mainly modified by LWP, whereas malic acid concentrations were impacted only by Chl. Both explanatory variables had additive effects on $\mathrm{pH}$ and potassium concentration, TPI and EA.
Subzones with low LWP recorded higher TSS and lower TA than subzones with high LWP. Maximum differences were detected in 2011 (26\% versus $25 \%$ and $2.4 \mathrm{~g}$ tartaric acid $\mathrm{L}^{-1}$ versus $2.8 \mathrm{~g}$ tartaric acid $\mathrm{L}^{-1}$, respectively), when the LWP variation coefficient was wider (Table 2). No significant differences were observed in 2013 , probably due to a greater availability of water in ripening period than in the other seasons, which could lead to a more homogeneous grape technological maturity in the subzones. Total precipitation registered from veraison to harvest were $28 \mathrm{~mm}$ in $2011,3 \mathrm{~mm}$ in 2012 , and $88 \mathrm{~mm}$ in 2013.

There were significant differences between tartaric acid concentrations in must from subzones with high and low LWP (0.18 $\mathrm{g} \mathrm{L}^{-1}$ versus $0.16 \mathrm{~g} \mathrm{~L}^{-1}$ ) only in 2012. Malic acid concentrations were higher in subzones with high Chl (4.2 $\mathrm{g} \mathrm{L}^{-1}$ versus $\left.3.5 \mathrm{~g} \mathrm{~L}^{-1}\right)$ and high LWP (4.1 g $\mathrm{L}^{-1}$ versus $3.5 \mathrm{~g} \mathrm{~L}^{-1}$ ) in 2013, without significant differences in 2011 and 2012. It is well known that water deficit accelerates sugar accumulation and acid breakdown in grape juice through ripening (Balint and Reynolds, 2017; Kounduras et al., 2006). Many studies have shown that tartrate concentration is little affected by plant water status, whereas malate concentration is differently altered depending on the extent or timing of water stress (Keller, 2015).

Water and iron status had significant effects on potassium concentration in the must (Table 4), tending to increase the values, since stress situations in the plants trigger a greater translocation of $\mathrm{K}^{+}$cations from leaves to berries (Boulton, 1980). High $\mathrm{K}^{+}$concentration in grape juice decreases concentration of free acids (in particular tartaric acid), resulting in an overall increase in $\mathrm{pH}$ (Gawel et al., 2000). On the other hand, the $\mathrm{pH}$ variation can be explained by lower leaf areas and greater exposure of clusters to sunlight in stressed plants, which might decrease malic acid synthesis and increase its catabolism (Kliewer and Lider, 1968). In the present study, water status had a stronger effect on must $\mathrm{pH}$ than iron chlorosis (Table 4). Differences between means from high to low LWP subzones were significant in 2011 and 2012 (data not shown), whereas no statistical differences were detected between subzones with high and low Chl.

Low levels of both Chl and LWP led to musts with higher concentrations of polyphenols and extractable anthocyanins. For example, in 2012, the mean TPI values in the double-stressed subzones increased by more than $27 \%$ compared to the subzones with better water and iron status (33.8 versus 41.4). In the 2012 season, EA increased $46 \%$ (537 $\mathrm{mg} \mathrm{kg}^{-1}$ versus $785 \mathrm{mg} \mathrm{kg}^{-1}$ ). These results agree with previous authors (Balint and Reynolds, 2014, 2017; Kounduras et al., 2006; Van Leeuwen et al., 2009), who reported that moderate water stress could reduce canopy density and berry weight, increasing sugar and anthocyanin content in the fruit. For Chaves et al. (2007), a moderate water deficit helps to balance the sink-source relationship in grapevines during ripening. 
However, water deficit in warm climates could contribute to increase the $\mathrm{pH}$ of grape juice, which results in undesirable effects on wine quality (Kodur, 2011).

The depression of photosynthesis in vines affected by strong iron deficiency led to a reduction in accumulation of substances in the berries during ripening, increasing total acidity (Martín et al., 2007). Nevertheless, low-moderate levels of iron availability for plants, similarly to water stress, might have some positive effects on grape quality, such as higher concentrations in sugar and anthocynin (Bavaresco et al., 2005). Low values of Chl and LWP in the study site were associated with reduced values of vigor, yield and berry weight, which tended to advance fruit ripening and, therefore, to reach better maturity indexes.

The chromatic characteristics of the must were more strongly affected by Chl than by LWP (Table 4). Must from chlorotic subzones had higher values in chroma and red component of the color and lower hue lightness than must from non-chlorotic subzones in all seasons. Increases of $\mathrm{C}^{*}$ coordinate in chlorotic subzones accounted for $13 \%$ (2011) and $18 \%$ (2013), while $\mathrm{a}^{*}$ was from $17 \%$ (2011) to $33 \%$ (2012) higher. These results are in agreement with those of Martín et al. (2007) and Meggio et al. (2010), who found a close relationships between the chromatic characteristics of the must and chlorophyll levels and other leaf pigments in leaves in vineyards affected by iron chlorosis.

Improved red pigmentation, observed in must from subzones with more water deficit and foliar chlorosis, is attributed to the fact that the plants produced smaller berries, which increased skin/pulp ratio, and therefore the anthocyanin content (Echeverria et al., 2017; Roby and Matthews, 2004; Romero et al., 2010). Moreover, moderate stress could have a direct effect on color, raising the production of anthocyanins (Dry et al., 2001). This would be a consequence of both an increase in fruit exposure to sunlight (lower canopy density) and a direct stimulation of anthocyanin biosynthesis enzymes (Romero et al., 2010). Bavaresco et al. (2005) suggested that iron is a constituent of enzymes involved in lignin synthesis thus iron deficiency may switch the shikimate pathway towards other phenolics including anthocyanins.

The PCA of yield and grape composition variables from each season explained between $59 \%$ (2013) and 73 $\%$ (2011) of the variation in the data with the first two components (Figures $1 \mathrm{C}$ and $1 \mathrm{~A}$, respectively). The total explained variation was higher when the variation in $\mathrm{Chl}$ and LWP was wider (Table 2). The parameters evaluating phenolic and chromatic potential of the grapes, as EA, TPI, $\mathrm{C}^{*}$ and $\mathrm{a}^{*}$, were highly correlated with the first principal component and showed negative correlation with total yield and berry size, according to Echeverria et al. (2017). The position of these variables in the PCA indicated no correlation with potassium concentration and TA of the must in the three years studied (Figures $1 \mathrm{~A}, \mathrm{~B}$ and $\mathrm{C})$.
In 2011 and 2012, the observations were grouped by LWP better than by Chl, since the black elements predominated in the right part of the first factorial plane (Figures $1 \mathrm{~A}$ and $\mathrm{B})$, showing low values of berry weight and high of TPI, C* and EA. However, in 2013 (Figure 1C), triangles (right) and squares (left) were separated regardless of their color, reflecting that subzones with higher TPI, $\mathrm{C}^{*}$ and EA corresponded to those with low Chl values.

According to the results exposed above, the linear regressions showed in Tables 5 and 6 indicated that either LWP or Chl, measured at the beginning of fruit ripening, could be used to predict the productive capacity and quality potential of the vineyard subzones studied. Nevertheless, there were few significant linear regressions of grape composition parameters on LAI, except for the anthocyanin content and must chromatic parameters in 2012. Since the end of the last century, different vegetation indexes from remote sense imagery, such as the normalized difference vegetation index (NDVI), have been used to delimit homogeneous sectors in precision viticulture, assuming that more vigorous vines produce higher yield but lower grape quality (Arnó et al., 2009). Our results suggest that, in vineyards simultaneously affected by water deficit and iron chlorosis, physiological indexes based on water status and foliar chlorophyll content estimations would be more efficient to predict grape quality than vegetation indexes.

Due to the additive effects detected in ANOVA (Table 4), regressions of yield, vigor and grape composition parameters on the $|\mathrm{Chl} / \mathrm{LWP}|$ ratio had in most cases higher coefficients of determination than those obtained on Chl and LWP separately (Tables 5 and 6). The ratio $|\mathrm{Chl} / \mathrm{LWP}|$ was strongly correlated to berry size, TPI, TAN and EA in all years studied. The chromatic characteristics of the must were significantly related to LWP in 2011 and 2012, and to $\mathrm{Chl}$ in all seasons. The $|\mathrm{Ch} / / \mathrm{LWP}|$ index had a good predicting value of $\mathrm{C}^{*}, \mathrm{~h}$ and $\mathrm{a}^{*}$ coordinates of musts in all seasons, and was better than Chl and LWP individually.

Our results demonstrate the potential interest of physiological indexes combining water status and foliar chlorosis for their use in precision viticulture. This tool should assist viticulturists and winemakers toward the adoption of management practices capable of adding value to their products. The $|\mathrm{Chl} / \mathrm{LWP}|$ index, obtained at the beginning of ripening, could serve to early spatial characterization of grape phenolic potential in rainfed vineyards affected by low-to-moderate iron deficiency. Further research should test the usefulness of this index under different genotypes, climates or soil conditions.

\section{Acknowledgements}

This research was supported by RTA201400077-C02-02 (from INIA and Ministerio de Economía y Competitividad, Spain) and VA013P17 (from Junta de Castilla y León) projects, and co-financed with FEDER Funds. The authors are grateful to Bodegas Emilio Moro S.L. for their collaboration to conduct this research. 

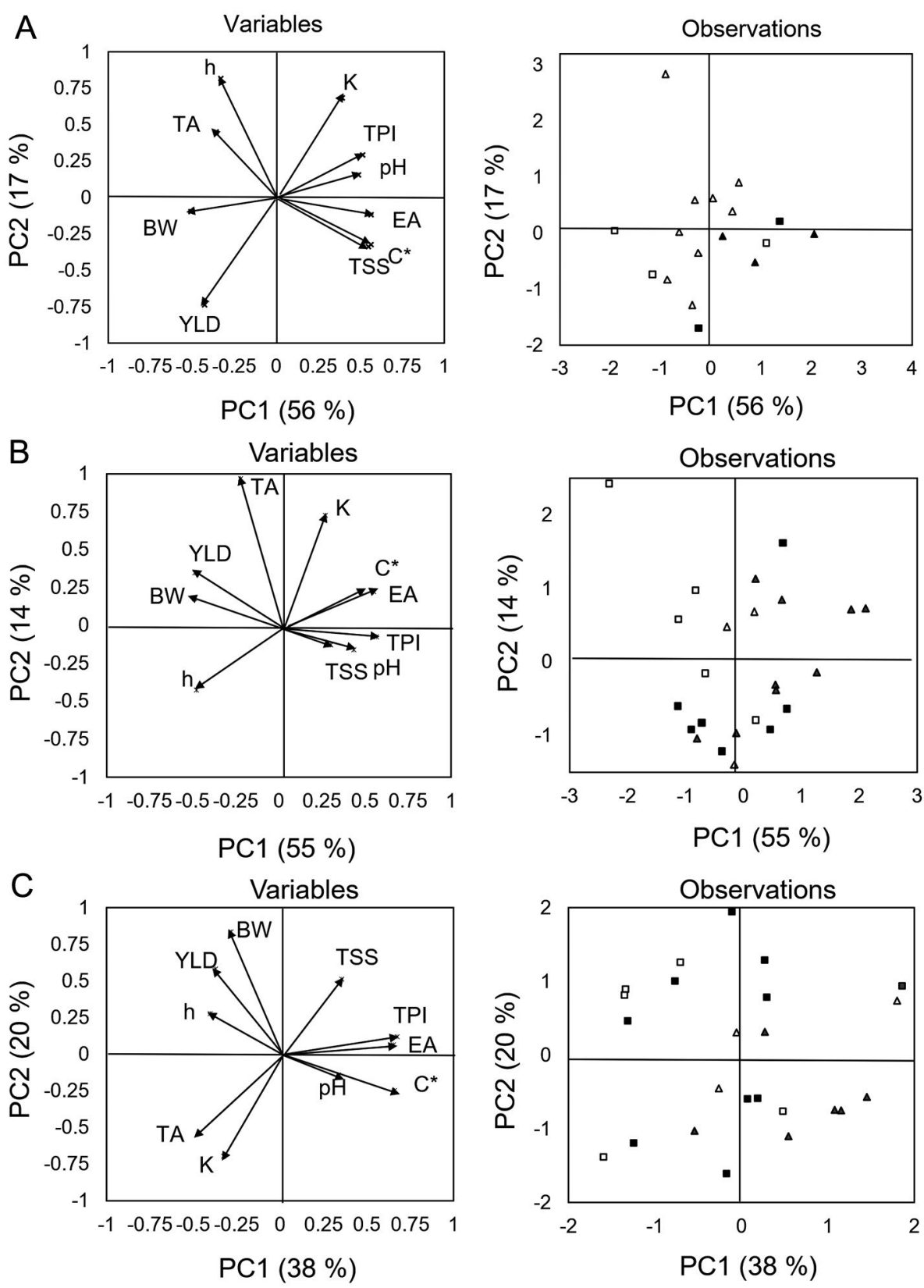

Figure 1 - Principal component analysis of yield and grape composition data obtained in 2011, 2012 and 2013 (Subfigures A, B and C, respectively). Left: loadings of variables on PC1 and PC2. Right: observation loadings. Variables: YLD = yield, BW = berry weight, EA = extractable anthocyanin content in grapes, TSS $=$ total soluble solids, $\mathrm{TA}=$ titratable acidity, $\mathrm{K}=$ potassium concentration, $\mathrm{TPI}=$ total polyphenol index, $\mathrm{C}^{*}=$ chroma, $\mathrm{h}=$ hue of the must. Observations were classified by high (squares) and low (triangles) foliar chlorophyll content, and by high (white) and low (black) leaf water potential at veraison.

\section{Authors' Contributions}

Conceptualization: González, M.R.; Martín, P. Data acquisition: González, M.R.; Hailemichael, G.; Catalina, A. Data analysis: González, M.R.; Hailemichael, G.; Catalina, A.; Martín, P. Design of Methodology: González, M.R.; Martín, P. Writing and editing: González, M.R.; Martín, P.

\section{References}

Agarwala, S.C.; Mehrotra, S.C. 1984. Iron-magnesium antagonism in growth and metabolism of radish. Plant and Soil 80: 355-361. Arnó, J.; Martínez-Casasnovas, J.A.; Ribes-Dasi, M.; Rosell, J.R. 2009. Review. Precision viticulture: research topics, challenges and opportunities in site-specific vineyard management. Spanish Journal of Agricultural Research 7: 779-790. 
Table 5 - Coefficients of determination $\left(R^{2}\right)$ and slopes of linear regressions of yield and grape composition parameters on leaf area index (LAl), predawn leaf water potential (LWP), foliar chlorophyll content (Chl) and the ratio Chl/LWP, in absolute value, registered at veraison.

\begin{tabular}{|c|c|c|c|c|c|c|c|c|c|}
\hline \multirow{2}{*}{$\frac{\text { Year }}{2011}$} & \multirow{2}{*}{$\begin{array}{l}\text { Parameters } \\
\text { Yield }\end{array}$} & \multicolumn{2}{|c|}{ LAl } & \multicolumn{2}{|c|}{ LWP } & \multicolumn{2}{|c|}{ Chl } & \multicolumn{2}{|c|}{ |Ch//LWP| } \\
\hline & & $(+)$ & $0.29^{* *}$ & $(+)$ & 0.03 & $(+)$ & 0.15 & $(+)$ & 0.14 \\
\hline & 100 berry weight & $(+)$ & 0.07 & $(+)$ & $0.26^{* *}$ & $(+)$ & $0.27^{* *}$ & $(+)$ & $0.42^{* *}$ \\
\hline & Total soluble solids & $(-)$ & 0.02 & $(-)$ & $0.38^{* *}$ & $(-)$ & 0.18 & $(-)$ & 0.49 ** \\
\hline & Titratable acidity & $(+)$ & 0.07 & $(+)$ & $0.21^{*}$ & $(+)$ & 0.04 & $(+)$ & $0.19^{*}$ \\
\hline & $\mathrm{pH}$ & $(-)$ & 0.16 & $(-)$ & 0.10 & $(-)$ & 0.09 & $(-)$ & 0.15 \\
\hline & Total polyphenol index & $(-)$ & 0.18 & $(-)$ & $0.26^{* *}$ & $(-)$ & $0.36^{\star *}$ & $(-)$ & $0.54^{* *}$ \\
\hline & Extractable anthocyanins & $(-)$ & 0.09 & $(-)$ & $0.30^{* *}$ & $(-)$ & 0.16 & $(-)$ & $0.47^{* *}$ \\
\hline & Total anthocyanins & $(+)$ & 0.02 & $(-)$ & $0.45^{* *}$ & $(-)$ & 0.15 & $(-)$ & $0.51^{* *}$ \\
\hline \multirow[t]{8}{*}{2012} & Yield & $(+)$ & 0.13 & $(+)$ & $0.37^{* *}$ & $(+)$ & $0.39^{* *}$ & $(+)$ & $0.53^{* *}$ \\
\hline & 100 berry weight & $(+)$ & $0.47^{* *}$ & $(+)$ & 0.50 * * & $(+)$ & $0.20^{*}$ & $(+)$ & $0.40^{* *}$ \\
\hline & Total soluble solids & $(-)$ & 0.01 & $(-)$ & 0.00 & $(-)$ & 0.12 & $(-)$ & 0.07 \\
\hline & Titratable acidity & $(-)$ & 0.01 & $(+)$ & $0.19^{*}$ & $(+)$ & 0.01 & $(+)$ & 0.10 \\
\hline & $\mathrm{pH}$ & $(+)$ & 0.02 & $(-)$ & $0.30^{* *}$ & $(-)$ & 0.13 & $(-)$ & $0.25^{*}$ \\
\hline & Total polyphenol index & $(-)$ & 0.15 & $(-)$ & $0.38^{* *}$ & $(-)$ & $0.35^{* *}$ & $(-)$ & $0.51^{* *}$ \\
\hline & Extractable anthocyanins & $(-)$ & $0.27^{* *}$ & $(-)$ & $0.37^{\text {* * }}$ & $(-)$ & $0.26^{* *}$ & $(-)$ & $0.33^{* *}$ \\
\hline & Total anthocyanins & $(-)$ & $0.28^{* *}$ & $(-)$ & $0.18^{*}$ & $(-)$ & $0.21^{*}$ & $(-)$ & $0.28^{*}$ \\
\hline \multirow[t]{8}{*}{2013} & Yield & $(-)$ & 0.06 & $(+)$ & $0.24^{* *}$ & $(+)$ & 0.07 & $(+)$ & $0.20^{*}$ \\
\hline & 100 berry weight & $(-)$ & 0.01 & $(+)$ & 0.13 & $(+)$ & $0.25^{* *}$ & $(+)$ & $0.33^{* *}$ \\
\hline & Total soluble solids & $(-)$ & 0.01 & $(-)$ & 0.11 & $(+)$ & 0.00 & $(-)$ & 0.01 \\
\hline & Titratable acidity & $(+)$ & $0.54^{* *}$ & $(+)$ & 0.13 & $(+)$ & 0.12 & $(+)$ & $0.20^{*}$ \\
\hline & $\mathrm{pH}$ & $(-)$ & $0.26^{* *}$ & $(-)$ & 0.04 & $(-)$ & 0.07 & $(-)$ & 0.09 \\
\hline & Total polyphenol index & $(-)$ & 0.09 & $(-)$ & $0.22^{*}$ & $(-)$ & 0.09 & $(-)$ & $0.20^{*}$ \\
\hline & Extractable anthocyanins & $(-)$ & 0.10 & $(-)$ & 0.09 & $(-)$ & $0.24^{\star *}$ & $(-)$ & $0.31^{* *}$ \\
\hline & Total anthocyanins & $(+)$ & 0.14 & $(-)$ & $0.25^{* *}$ & $(-)$ & 0.15 & $(-)$ & 0.30 ** \\
\hline
\end{tabular}

${ }^{*}$ Significant $p<0.05 ;{ }^{*}$ Significant $p<0.01$.

Table 6 - Coefficients of determination $\left(R^{2}\right)$ and slopes of linear regressions of CIELab color parameters of the must on leaf area index (LAl), predawn leaf water potential (LWP), foliar chlorophyll content (Chl) and Chl/LWP, in absolute value, registered at veraison.

\begin{tabular}{|c|c|c|c|c|c|c|c|}
\hline Year & Parameter & & LAl & LWP & & $\mathrm{Chl}$ & $|\mathrm{Chl} / \mathrm{LWP}|$ \\
\hline \multirow[t]{5}{*}{2011} & $\mathrm{C}^{*}$ & $(-)$ & 0.07 & (-) $0.43^{* *}$ & $(-)$ & $0.24^{* *}$ & (-) $0.61^{* *}$ \\
\hline & $\mathrm{h}$ & $(+)$ & 0.02 & (+) $0.31^{* *}$ & $(+)$ & 0.03 & (+) $0.27^{* *}$ \\
\hline & L & $(+)$ & 0.08 & (+) $0.37^{* *}$ & $(+)$ & $0.36^{* *}$ & (+) $0.64^{* *}$ \\
\hline & $a^{*}$ & $(-)$ & 0.05 & (-) $0.35^{* *}$ & $(-)$ & $0.31^{* *}$ & (-) $0.62^{* *}$ \\
\hline & $b^{*}$ & $(+)$ & 0.04 & (+) $0.28^{* *}$ & $(-)$ & 0.00 & (+) 0.14 \\
\hline \multirow[t]{5}{*}{2012} & $C^{*}$ & $(-)$ & $0.29^{* *}$ & (-) $0.29 * *$ & $(-)$ & $0.36^{* *}$ & (-) $0.42^{* *}$ \\
\hline & $\mathrm{h}$ & $(+)$ & $0.25^{\star *}$ & (+) 0.15 & $(+)$ & $0.26^{* *}$ & (+) $0.27^{* *}$ \\
\hline & L & $(+)$ & $0.25^{* *}$ & (+) $0.43^{* *}$ & $(+)$ & $0.31^{* *}$ & (+) $0.45^{* *}$ \\
\hline & $a^{*}$ & $(-)$ & $0.29^{* *}$ & (-) $0.26^{* *}$ & $(-)$ & $0.35^{* *}$ & (-) $0.39^{* *}$ \\
\hline & $b^{*}$ & $(+)$ & 0.08 & (+) 0.03 & $(+)$ & 0.01 & (+) 0.01 \\
\hline \multirow[t]{5}{*}{2013} & $C^{*}$ & $(-)$ & 0.16 & $(-) 0.07$ & $(-)$ & $0.41^{\text {** }}$ & (-) $0.45^{* *}$ \\
\hline & $\mathrm{h}$ & $(+)$ & $0.29 * *$ & (-) 0.00 & $(+)$ & $0.31^{\text {* * }}$ & (+) $0.21^{*}$ \\
\hline & $L$ & $(+)$ & 0.06 & (+) 0.06 & $(+)$ & 0.03 & (+) 0.06 \\
\hline & $a^{*}$ & $(-)$ & $0.26^{* *}$ & (-) 0.05 & $(-)$ & $0.42^{* *}$ & (-) $0.43^{* *}$ \\
\hline & $b^{*}$ & $(+)$ & $0.19^{*}$ & (-) 0.05 & $(+)$ & 0.08 & (+) 0.02 \\
\hline
\end{tabular}

${ }^{*}$ Significant $p<0.05 ;{ }^{* *}$ Significant $p<0.01$.

Balint, G.; Reynolds, A.G. 2014. Effect of different irrigation strategies on vine physiology, yield, grape composition and sensory profiles of Vitis vinifera L. Cabernet Sauvignon in a cool climate area. Journal International des Sciences de la Vigne et du Vin 48: 269-292.
Balint, G.; Reynolds, A.G. 2017. Irrigation strategies impact Baco noir grapevines in Ontario. II. Fruit composition and wine sensory analysis. American Journal of Enology and Viticulture 68: 310-324.

Bavaresco, L.; Bertamini, M.; Iacono, F. 2006. Lime-induced chlorosis and physiological responses in grapevine (Vitis vinifera L. cv. Pinot blanc) leaves. Vitis 45: 45-46.

Bavaresco, L.; Civardi, S.; Pezzutto, S.; Vezzulli, S.; Ferrari, F. 2005. Grape production, technological parameters, and stilbenic compounds as affected by lime-induced chlorosis. Vitis 44: 63-65.

Bavaresco, L.; Giachino, E.; Colla, R. 1999. Iron chlorosis paradox in grapevine. Journal of Plant Nutrition 22: 1589-1597.

Boulton, R. 1980. The general relationship between potassium, sodium and $\mathrm{pH}$ in grape juice and wine. American Journal of Enology and Viticulture 31: 182-186.

Chaves, M.M.; Santos, T.P.; Souza, C.R.; Ortuno, M.F.; Rodrigues, M.L.; Lopes, C.M.; Maroco, J.P.; Pereira, J.S. 2007. Deficit irrigation in grapevine improves water-use-efficiency without controlling vigour and production quality. Annals of Applied Biology 150: 237-252.

Cortell, J.M.; Halbleib, M.; Gallagher, A.V.; Righhetti, T.L.; Kennedy, J.A. 2005. Influence of vine vigor on grape (Vitis vinifera L. cv. Pinot Noir) and wine proanthocyanidins. Journal of Agricultural and Food Chemistry 53: 5798-5808.

Dry, P.R.; Loveys, B.R.; McCarthy, M.G.; Stoll, M. 2001. Strategic irrigation management in Australian vineyards. Journal International des Sciences de la Vigne et du Vin 35: 45-61. 
Echeverría, G.; Ferrer, M.; Mirás-Avalos, J.M. 2017. Effects of soil type on vineyard performance and berry composition in the Río de la Plata coast (Uruguay). OENO One 51: 251-261.

European Commission. 1990. Regulation (EEC) $N^{\circ}$ 2676/90 of $17 / 09 / 1990$. Community methods for the analysis of wines. Official Journal of the European Communities L272 (3/10/1990): 0001-0192.

Flexas, J.; Bota, J.; Escalona, J.M.; Sampol, B.; Medrano, H. 2002. Effects of drought on photosynthesis in grapevines under field conditions: an evaluation of stomatal and mesophyll limitations. Functional Plant Biology 29: 461-471.

Gawel, R.; Ewart, A.; Cirami, R. 2000. Effect of rootstock on must and wine composition and the sensory properties of Cabernet Sauvignon grown at Langhorne Creek, south Australia. Australian and New Zealand Wine Industry Journal 15: 67-73.

Gruber, B.; Kosegarten, H. 2002. Depressed growth of nonchlorotic vine grown in calcareous soil is an iron deficiency symptom prior lo leaf chlorosis. Journal of Plant Nutrition and Soil Science 165: 111-117.

Hailemichael, G.; Catalina, A.; González, M.R.; Martín, P. 2016. Relationships between water status, leaf chlorophyll content and photosynthetic performance in tempranillo vineyards. South African Journal of Enology and Viticulture 37: 149-156.

International Organization of Vine and Wine [OIV]. 1996. Resolution VITI 4/95. Foliar diagnosis: a harmonized method = Résolution VITI 4/95. Diagnostic foliare: une méthode harmonisée. Bulletin de l'OIV 69: 779-780 (in French).

Keller, M. 2015. The Science of Grapevines: Anatomy and Physiology. 2ed. Academic Press, San Diego, CA, USA.

Kliewer, W.M.; Lider, L.A. 1968. Influence of cluster exposure to the sun on the composition of Thompson Seedless fruit. American Journal of Enology and Viticulture 19: 175-184.

Kodur, S. 2011. Effects of juice $\mathrm{pH}$ and potassium on juice and wine quality, and regulation of potassium in grapevines through rootstocks (Vitis): a short review. Vitis 50: 1-6.

Koundouras, S.; Marinos, V.; Gkoulioti, A.; Kotseridis, Y.; VanLeeuwen, C. 2006. Influence of vineyard location and vine water status on fruit maturation of non-irrigated cv. Agiorgitiko (Vitis vinifera L.). Effects on wine phenolic and aroma components. Journal of Agriculture and Food Chemistry 54: 5077-5086.

Li, T.; Hao, X.M.; Kang, S.Z.; Leng, D. 2017. Spatial variation of winegrape yield and berry composition and their relationships with spatiotemporal distribution of soil water content. American Journal of Enology and Viticulture 68: 369-377.

Martín, P.; Zarco-Tejada, P.J.; González, M.R. 2008. Nutritional diagnosis and fertilizer recommendations in the limestone soils of Ribera de Duero = Diagnostico nutricional $\mathrm{y}$ recomendaciones de abonado en suelos calizos de la Ribera de Duero. Vida Rural 270: 26-32 (in Spanish).

Martín, P.; Zarco-Tejada, P.J.; González, M.R.; Berjón, A. 2007. Using hyperspectral remote sensing to map grape quality in 'Tempranillo' vineyards affected by iron chlorosis. Vitis 46: 7-14.

Meggio, F.; Zarco-Tejada, P.J.; Núñez, L.C.; Sepulcre-Cantó, G.; González, M.R.; Martín, P. 2010. Grape quality assessment in vineyards affected by iron deficiency chlorosis using narrowband physiological remote sensing indexes. Remote Sensing of Environment 114: 1968-1986.
Millaleo, R.; Reyes-Díaz, M.; Ivanov, A.G.; Mora, M.L.; Alberdi, M. 2010. Manganese as essential and toxic element for plants: transport, accumulation and resistance mechanisms. Journal of Soil Science and Plant Nutrition 10: 470-481.

Ojeda, H.; Andara, C.; Kraeva, E.; Carbonneau, A.; Deloire, A. 2002. Influence of pre- and postveraison water deficit on synthesis and concentration of skin phenolic compounds during berry growth of Vitis vinifera cv. Syrah. American Journal of Enology and Viticulture 53: 261-267.

Pirie, A.J.G.; Mullins, M.G. 1980. Concentration of phenolics in skin of grape berries during fruit development and ripening. American Journal of Enology and Viticulture 31: 34-36.

Roby, G.; Matthews, M.A. 2004. Relative proportions of seed, skin and flesh, in ripe berries from Cabernet Sauvignon grapevines grown in a vineyard either well irrigated or under water deficit. Australian Journal of Grape and Wine Research 10: 74-82.

Romero, P.; Fernández-Fernández, J.I.; Martinez-Cutillas, A. 2010. Physiological thresholds for efficient regulated deficitirrigation management in winegrapes grown under semiarid conditions. American Journal of Enology and Viticulture 61: 300-312.

Saint-Cricq de Gaulejac, N.; Vivas, N.; Glories, Y. 1998. Phenolic maturation of red grapes. Relation with the quality of wines. Comparison of the cultivars Merlot and Tempranillo = Maturation phénolique des raisins rouges. Relation avec la qualité des vins. Comparaison des cépages Merlot et Tempranillo. Le Progrés Agricole et Viticole 115: 306-318 (in French).

Sánchez-de-Miguel, P.; Baeza, P.; Junquera, P.; Lissarrague, J.R. 2010. Vegetative development: total leaf area and surface area indexes. p. 31-44. In: Delrot, S.; Medrano, H.; Or, E.; Bavaresco, L.; Grando, S., eds. Methodologies and results in grapevine research. Springer Science+Business, Dordrecht, The Netherlands.

Tagliavini, M.; Rombolà, A.D. 2001. Iron deficiency and chlorosis in orchard and vineyard ecosystems. European Journal of Agronomy 15: 71-92.

Val, J.; Monge, E.; Heras, L.; Abadía, J. 1987. Changes in photosynthetic pigment composition in higher plants as affected by iron nutrition status. Journal of Plant Nutrition 10: 995-1001.

Van-Leeuwen, C.; Friant, P.; Choné, X.; Tregoat, O.; Koundouras, S.; Dubourdieu, D. 2004. The influence of climate, soil and cultivar on terroir. American Journal of Enology and Viticulture 55: 207-217.

Van-Leeuwen, C.; Tregoat, O.; Choné, X.; Bois, B.; Pernet, D.; Gaudillère, J.P. 2009. Vine water status is a key factor in grape ripening and vintage quality for red Bordeaux wine: how can it be assessed for vineyard management purposes? Journal International of Sciences de la Vigne et du Vin 43: 121-134.

Zarco-Tejada, P.J.; Catalina, A.; González, M.R.; Martín, P. 2013. Relationships between net photosynthesis and steady-state chlorophyll fluorescence retrieved from airborne hyperspectral imagery. Remote Sensing of Environment 136: 247-258.

Zoecklein, B.W.; Fugelsang, K.C.; Gump, B.H.; Nury, F.S. 1990. Production Wine Analysis. Van Nostrand-Reinhold, New York, NY, USA. 